\title{
The Effectiveness of the PBL-STEM Model in Online Learning to Improve Students' Scientific Attitudes
}

\author{
Indarini Dwi Pursitasari ${ }^{*} \quad$ Bibin Rubini $^{1} \quad$ Clarissa Desyana Putri ${ }^{2}$ \\ 1.Post graduate School of Universitas Pakuan, PB. BOX 452 Bogor, Indonesia \\ 2.SMA Pasundan 1 Cianjur, Indonesia
}

\begin{abstract}
This study aims to describe the effectiveness of the PBL-STEM model in online learning to improve students' scientific attitudes in Work and Energy materials. This research is a pre-experimental study with a One Group Pretest-Posttest Design. Online learning used Google Classroom and Jitsi Meet applications. Both applications are used because they are easier to use compared to other distance learning application programs. The results showed that $\mathrm{N}$-gain of the scientific attitudes was 0.47 , and the students' response to learning was $81 \%$, which means that it is categorized as good. The aspect that has the highest $\mathrm{N}$-gain is the aspect of Intense Curiosity. This research concludes that online learning using PBL-STEM model is effective to improve students' scientific attitudes.
\end{abstract}

Keywords: PBL-STEM, Work and energy, Scientific attitudes

DOI: $10.7176 / \mathrm{JEP} / 11-29-04$

Publication date:October $31^{\text {st }} 2020$

\section{Introduction}

Physics lessons are often felt to be challenging to learn and often make students complain, and as a result, students being less motivated in learning physics (Minan, 2016). The implementation of learning is still not related to everyday life and technological developments. Learning outcomes are not only seen from changes in knowledge and skills but also changes in attitudes. One of the attitudes that need to be developed in learning physics is scientific attitudes. Scientific attitude refers to a way of thinking without prejudice (John \& Ademola, 2014; Stacey O. et al., 2018; Fadiri et al., 2020). This attitude is usually reflected in a person's rational, consistent, and objective thinking towards the relevant circumstances. Scientific attitude is characterized by curiosity and open-mindedness that is critical, logical, objective, honest, and straightforward (Ali, 2013; John \& Ademola, 2014). Scientific attitude plays a vital role in learning because it affects learning outcomes according to research conducted by Fitriani (2020) which states that scientific attitudes affect student's skills. It is indicated by the correlation of the increase in scientific attitudes and thinking skills by $85 \%$. A person with an excellent scientific attitude will not accept anything that is not proven and illogical information that is processed without wisdom and has a strong belief in himself (John \& Ademola, 2014). Scientific attitudes can be measured through one's achievements in science, self-concept, interest in science, and motivation for science (Alam, 2017; van Uum et al., 2019).

Based on several studies, it is stated that the scientific attitude still has low and negative values. The reason is that the teacher has not trained students to develop scientific attitudes in the classroom. Therefore, students become less tolerant of other students. It is following the research conducted by Firdaus and Darmadi (2017), which revealed that students' scientific attitudes were in a low category. Findings from Şentürk and Özdemir's (2014) study suggest that students' lack of flexibility in class discussions can cause them to have a weak interest in learning and collaboration skills. Students' low environmental sensitivity may be the result of students' intolerance of the predicament of their peers. Other possible causes of students' poor scientific attitudes include untrained scientific attitudes and ineffective learning strategies that focus only on improving student's skills (Şentürk \& Özdemir, 2014).

At the time of the Covid-19 pandemic, students were required to take part in online learning, which was very dull. Therefore, learning must make students more enthusiastic and understand the material well and have a scientific attitude. Scientific attitude needs to be built and developed in learning physics. Students' scientific attitudes are an essential part of the affective domain of learning physics. Scientific attitudes can be obtained from the experience and learning process following the results of research conducted by Devi (2019) regarding students' scientific attitudes. Students need to have and show a scientific attitude when they carry out the learning process (Muliani, 2019). Scientific attitude is essential for teachers to pay attention to when studying science, especially physics. (Wijaya, 2019). Scientific attitude in physics is a reaction that a person takes when there is an action that is influenced by several factors in studying physics in the form of rejection or acceptance of a concept or theory (Sukarni, 2020; Fitriani, 2020).

Based on this, to be able to train and accustom students to be actively involved and enthusiastic about participating in learning, innovative, communicative, and collaborative learning models are needed. One form of innovative learning is Problem Based Learning (PBL). The PBL model is a learning model that uses real problems to acquire PBL knowledge through active student participation. PBL can instil the basics of scientific thinking and develop thinking mental, which is very much needed in 21 st-century learning (Diani, 2019). The application of 
PBL has been carried out by Mansur (2018) regarding the application of the Problem Based Learning model that can improve learning outcomes in Physics Science. Research conducted by Sulardi (2015) regarding the development of the problem-based learning model of physics resulted in a significant increase in training students' critical thinking skills. The research conducted by Yulianti (2019) using PBL can improve conceptual understanding and critical thinking. Another PBL research is from Diani (2019) regarding Scaffolding in Physics learning based on Problem Based Learning (PBL), resulting in an increased understanding of concepts and selfefficacy in students.

Revolution 4.0 requires individuals to be able to connect science, technology, engineering, and mathematics (STEM). This approach is an effective way to facilitate and maintain the integration of STEM disciplines in a plural manner (Estapa \& Tank, 2017). This approach has been widely used in learning physics. The results of Afriana's (2016) research on the application of STEM-Integrated Project-Based Learning can improve students' Science Literacy outcomes based on Gender. Research by Irfana (2018) on the development of STEM-based PBL increases students' creative thinking skills. Based on the results of research on the application of the PBL model and the STEM approach in learning, it is necessary to research the integration of PBL-STEM in online physics learning to improve students' scientific attitudes. It needs to be done so that students are freer to express their curiosity about physics material. According to the National Research Council (2011) and Yulianti (2019), integration of STEM into PBL involves scientific practice and engineering practice. PBL-STEM online learning facilitates students to develop and acquire knowledge, skills, and attitudes of science through a series of activities to design a tool. The teacher is no longer a source of knowledge but instead acts as a facilitator (Kurniawan, 2019). Student activities design tools in learning with the PBL-STEM model to solve problems faced in learning physics. When students face problems, students express their curiosity to be able to understand the problems and try to solve them. According to Hardiati (2019), giving problems is very useful to increase students' curiosity. Furthermore, the products produced by students through learning can produce a structured concept (Astuti et al., 2019; Hidayati et al., 2020).

The research objective was to improve students' scientific attitudes after learning online using the integrated PBL-STEM model. This PBL-STEM model is also carried out online using the google classroom and Jitsii.meet applications. The materials used in this research are work and energy materials which are only limited to the materials of work, kinetic energy, potential energy, and mechanical energy, where all of these materials are done by searching for concepts by tools made by students by learning using the PBL-STEM syntax model. The scientific attitude taken is the scientific attitudes with objective aspects, high curiosity, open thinking, disbelief, and positive thinking when faced with failure.

\section{Research method}

The research method used in this study was Pre-Experimental (Cook \& Campbel, 1979) with One Group PretestPosttest Design. This study used a purposive sampling method where the subject was not chosen randomly but rather took samples with a specific purpose (Fraenkel et al., 2012) so that the goal of increasing scientific attitudes is seen only in one class with 23 students. The sample was given two questionnaires regarding the students' scientific attitudes at the beginning and end of the PBL-STEM learning process. The first questionnaire is a Likert scale questionnaire, while the second questionnaire is an interview questionnaire as a supporting questionnaire. It is done because learning is online, and direct observation cannot be made. Observations are objective when the learning videos conducted by students have been collected ultimately, and then the video is analyzed descriptively by the researcher. The population in this study were 43 students of Grade 10 MIPA Class in a high school in Cianjur.

After the questionnaire data was obtained, then the questionnaire was analyzed using N-gain analysis by looking at the results of the first questionnaire score at the time before learning and after learning. Based on the results of the calculation of N-gain, then categorized by the criteria is shown in Table 1 .

Table 1: Criteria for Normalized Gain

\begin{tabular}{ll}
\hline Score N-Gain & Criteria for Normalized Gain \\
\hline $0.7<\mathrm{N}-$ Gain & High \\
$0.3 \leq \mathrm{N}-$ Gain $\leq 0.7$ & Medium \\
$\mathrm{N}-$ Gain $<0.3$ & Low \\
\hline
\end{tabular}

Furthermore, the score of the scientific attitude questionnaire was analyzed using the Statistical Package for Social Sciences (SPSS) application to find a hypothesis test using the paired sample t-test, which is part of the parametric statistics. Therefore, the rule in parametric statistics is that the research data must be normally distributed. If the data is not normally distributed, then the data analysis is continued with non-parametric statistics using Wilcoxon Signed Ranks. The basis for making research decisions is Sig. (2-tailed) $<0.05$, then there is a significant difference between the attitude questionnaire scores before and after learning. If Sig. (2-tailed) $>0.05$, so there is no significant difference between the attitude questionnaire scores before and after learning. Data can be known to be normally distributed or not after the normality test is carried out through the Kolmogorov Smirnov 
test with SPSS version 23. Interpretation of the normality test with Kolmogorov Smirnov is that if the significance value is at probability $>0.05$, the data is said to be normally distributed. Conversely, if the probability value $<$ 0.05 , the data is said to be not normally distributed.

The population in this study was 43 tenth-grade students consisting of 17 male students and 26 female students. All samples have not received material on work and energy and have similar learning outcomes. Sampling was done by using the purposive sampling technique (Creswell, 2012). Samples were taken that will use learning with the online PBL-STEM model regularly and are not constrained by the network. The research steps included: 1) Observation in class; 2) Preparing lesson plans to be implemented; 3) Providing a questionnaire on scientific attitudes before learning takes place; 4) Carrying out research with PBL-STEM learning; 5) Providing a questionnaire on scientific attitudes after learning takes place; 6) Managing the scientific attitude questionnaire score data; 7) Analyzing the results of the managed data; 8) Making conclusions.

\section{Research results}

Scientific attitudes include the objective, intense curiosity, open-mindedness, scepticism, thinking positively about failure (Carin \& Sund, 1989). Students' scientific attitudes before and after participating in learning using PBLSTEM are shown in Table 2.

Table 2: Students' scientific attitudes through PBL-STEM learning

\begin{tabular}{lcc}
\hline Description of & \multicolumn{2}{c}{ Scientific attitude } \\
\cline { 2 - 3 } & Early & Final \\
\hline Highest score & 93 & 95 \\
Lowest score & 45 & 70 \\
Average & 71 & 85 \\
Standard deviation & 13.83 & 7.12 \\
Variance & 191.18 & 50.68 \\
N-gain & & 0.47 \\
\hline
\end{tabular}

The results showed that the average score of students' scientific attitudes before and after learning using PBLSTEM are 71 and 85 with an increase (N-gain) of 0.47 (moderate category). The significance test for the improvement of students' scientific attitudes through learning using PBL-STEM was carried out by using the tpair test. The results of the statistical tests are presented in Table 4.

Table 3: The results of the statistical test of students' scientific attitudes

\begin{tabular}{|c|c|c|c|c|c|c|c|}
\hline \multirow[t]{2}{*}{ Data } & \multirow[t]{2}{*}{$\mathrm{N}$} & \multicolumn{2}{|c|}{ Normality Test } & \multicolumn{2}{|c|}{ Homogeneity Test } & \multicolumn{2}{|r|}{ Test } \\
\hline & & Sign. & Conclusion & Sign. & Conclusion & Sign & Conclusion \\
\hline $\begin{array}{l}\text { pretest } \\
\text { posttest }\end{array}$ & $\begin{array}{l}23 \\
23\end{array}$ & $\begin{array}{l}0.051 \\
0.164\end{array}$ & $\begin{array}{l}\text { Normal } \\
\text { Normal }\end{array}$ & 0.000 & Not homogeneous & 0.000 & Significant \\
\hline
\end{tabular}

Table 3 shows that the two groups of data normally distributed but not homogeneous because it has a sig value. $<0.05$, which is 0.000 . Although not homogeneous, this does not affect the difference in the mean of the two data. The difference test results show the sig value of $0.000<0.05$, so it can be concluded that there are differences in the average of scientific attitudes before and after the use of PBL-STEM learning. Obtaining a detailed scientific attitude by the component of scientific attitudes by Carin and Sund (1989) is presented in Table 4.

Table 4: Students' scientific attitudes in terms of aspects

\begin{tabular}{lccc}
\hline \multirow{2}{*}{ Aspects of scientific attitudes } & \multicolumn{3}{c}{ Scientific attitude (\%) } \\
\cline { 2 - 4 } Objective & Before & After & N-gain \\
Intense Curiosity & 65.21 & 84.24 & 55 \\
Open-mindedness & 73.37 & 88.32 & 56 \\
Skepticism & 76.09 & 83.70 & 32 \\
Thinking positively about failure & 66.85 & 74.46 & 23 \\
\hline
\end{tabular}

Based on Table 4, an increase in the average value of N-Gain for every aspect of students' scientific attitude has increased with a moderate category. The highest increase is Intense Curiosity, while the lowest increase is scepticism.

After learning Work and Energy using PBL-STEM, which is done online, students respond to the implementation of the learning. The student responses are grouped into three, with the average value in Table 5. Table 5. Students' Responses to PBL-STEM Learning

\begin{tabular}{lc}
\hline Statement & Students'responses (\%) \\
\hline Interest of students in the PBL-STEM learning process & 81 \\
Suitability of work and energy materials using PBL STEM learning & 82 \\
Student interest in developing scientific attitudes & 81 \\
\hline
\end{tabular}


Table 5 shows that students give adequate responses to the implementation of work and energy learning using PBL-STEM with an overall average of $81 \%$.

\section{Discussion}

PBL-STEM learning is a development of the PBL learning model using the STEM approach. The syntax of the PBL-STEM model has five learning phases, where the first phase starts with student orientation to the problemAsking questions and defining the problem (using the Jitsi application), in this phase, the teacher provides presentation related to learning material and students are asked to ask questions and express initial hypothesis. The second phase is Organizing students to learn - Planning and carrying out investigations (Using the Google Classroom Application) The teacher provides worksheets and instructs to make planning tools that will answer problems from the concepts to be studied. The third phase is Guiding individual or group experiences - Planning and carrying out investigations (reports in the form of videos sent to google classroom). The teacher invites students to make props according to planning and concepts. The fourth phase has three stages, namely Developing and presenting the work - Developing and using modelling. At this stage, the teacher asks students to try and improve it before it is finally presented. Then Develops and presents the work - Using mathematics and computational thinking, the teacher asks students to retrieve data from the experiment of the tool and connect it with mathematical formulation, graphics, and data with concepts, the last stage in this fourth phase is Developing and presenting the results of work -Building explanations and designing solutions. At this stage, the teacher asks students to make explanations and design solutions to answer questions. In this fourth phase, students are asked to make a video as a report and send it through the Google Classroom application. The last phase, namely the fifth phase, has three stages of learning, namely Analyzing and evaluating the process - Analyzing and interpreting the data where After the phase IV, video is wholly collected, the teacher returns to the Jitsi application. Then the learning was continued by analyzing and interpreting the data through video viewing of several students as a sample to be able to comment on the props made by individuals. The next stage is analyzing and evaluating the process - Engaging in arguments from the evidence at this stage. The teacher asks students to comment and argue about the results of the design of tools, data, and solutions to problems. The last one is analyzing and evaluating the process - Obtaining, evaluating, and communicating information. The teacher asks three people to be able to conclude learning outcomes ultimately and following problem solutions based on what they have done. The teacher asks students to send the students' worksheet that has been done through the google classroom.

The use of STEM integration in the PBL model has created a learning atmosphere that enables students to absorb lessons well. If they catch the meaning in the academic material and school assignments, they can relate new information to the knowledge and experience they already have before (Karim \& Normaya, 2015) so that PBL-STEM learning is said to be capable of improving students' scientific attitudes which will later make these attitudes able to face 21 st-century skills. In line with research conducted by Anjirawaroj (2020) which states that learning that uses investigation as its basis has been recognized as support for scientific achievement and students' scientific attitudes.

From this research, the increase in scientific attitudes is in the moderate category with a value of 0.47 . There are five aspects studied regarding scientific attitudes, namely objective, intense curiosity, scepticism, openmindedness, and thinking positively about failure. Based on the results of the analysis of the scientific attitude aspect in table 4, the highest $\mathrm{N}$-gain results were shown in the Intense Curiosity aspect or high curiosity with an $\mathrm{n}$-gain value of 0.56 because students became increasingly curious about a concept, so they used various kinds of media when doing PBL-STEM online learning. Besides, the presentation of pictures and questions also aims to provide a stimulus to arouse students' curiosity in solving these problems (Suryani, 2019). Activities of formulating problems and making hypotheses will help optimize the curiosity of students to recognize the subject matter massively and how to solve these problems. A person who has a scientific attitude when he sees natural events will be aroused to want to know more about what, how, and why the event or phenomenon occurred (Mayangsari, 2020). This finding is in line with research conducted by Nugraha (2020), which states that this aspect of intense curiosity is an aspect that has a significant increase compared to other aspects of scientific attitudes.

Meanwhile, the aspect of scepticism had the lowest score with a value of 0.23 . It is because students quickly feel satisfied with the concepts obtained so that students do not find out in more detail about what they think is not clear, and they only accept existing information without further investigating. Sudarmini (2015) revealed that students who have a poor scientific attitude are characterized by a sense of being quickly satisfied so that these students will need more guidance. In line with other research studies with a scientific attitude, students should not be easily satisfied and always have a critical thinking attitude by repeating the experimental activities carried out to obtain relevant experimental results. Students are expected to be able to change their initial views when there are new facts that do not match their initial views so that it shows that disbelief and quickly feeling satisfied are bad attitudes (Parwati, 2020; Annam, 2020). In line with research conducted by Kareem (2020), it could be that students do not carry out the learning process in the right way, especially during practice. Because every student must carry out all learning activities, each learning component has a vital role in improving attitudes in learning. 
Science is fundamental for teachers to pay attention when learning science, especially physics. Understanding a learning concept requires practice and an attitude that can be used to increase knowledge and assist him in applying or developing skills and knowledge, this attitude is the scientific attitude that is the most concerning (Wijaya, 2018; Ates, 2011). In line with the research conducted by Ilmi (2020), it is revealed that the use of media is essential to be able to improve students' scientific attitudes, where this scientific attitude is critical for the improvement of other skills.

The scientific attitude towards PBL-STEM learning can be seen from the results of testing the research hypothesis. Based on the t-paired sample test for scientific attitudes, a significance level of $0.000(<0.050)$ is obtained, the decisions taken based on these data are that $\mathrm{H}_{0}$ is rejected and $\mathrm{H}_{1}$ is accepted. It can be concluded that there are differences in the increase in students' scientific attitudes before and after learning. This increase is in line with Saepudin' (2020) study to identify potential scientific attitudes of students requiring a learning environment that can explore students' scientific potential so that the PBL-STEM model can adequately accommodate the online learning environment and see students' scientific attitudes. Research conducted by Dewi (2020) reveals that to make students active in activities by utilizing science, understanding technology to solve problems and make decisions to create scientific knowledge is the result of improving an excellent scientific attitude so that the scientific attitude is the most crucial basis in learning.

\section{Conclusion}

Based on the results of data analysis and discussion, it can be concluded that the implementation of learning using the online PBL-STEM model during a pandemic like this is one of the right solutions so that the learning process takes place optimally. There was an increase in students' scientific attitudes after giving PBL-STEM learning that got positive responses and played an active role during learning, which was seen in data that were normally distributed and had an average difference between scientific attitudes before learning and after learning. From the research, the increase in scientific attitudes is in the moderate category with $\mathrm{N}$-gain value of 0.47 . The aspect with the highest value was Intense Curiosity aspect with a value of 0.56, and the aspect with the lowest score was Skepticism aspect with a value of 0.23 .

\section{Acknowledgment}

Thank you very much to the Deputy for Strengthening Research and Development of the Ministry of Research Technology / National Innovation Research Agency who has provided a Master Thesis Research grant for the 2020 Fiscal Year..

\section{References}

Afriana, J., Permanasari, A., \& Fitriani, A. (2016). Penerapan Project Based Learning terintegrasi STEM untuk meningkatkan literasi sains siswa ditinjau dari gender. Jurnal Inovasi Pendidikan IPA. 2(2), 202-212.

Alam, Q. (2017). Impact of the school outreach tour program of Citizens Archive of Pakistan on students' perceptions and attitudes. International Journal of Instruction, 10(1), 289-306.

Ali, M. M., Yager, R. E., Hacieminoglu, E., \& Caliskan, I. (2013). Changes in student attitudes regarding science when taught by teachers without experiences with a model professional development program. School Science and Mathematics, 113(3), 109-119.

Anjirawaroj, S. (2020). The effect of CIPPA instructional model and inquiry method on nursing students' achievement and scientific attitude. JPBI (Jurnal Pendidikan Biologi Indonesia) 6(2), 181-188

Annam, S. Susilawati, \& Ayub, S. (2020). Pengaruh model pembelajaran POE (Predict-Observe-Explain) terhadap kemampuan pemecahan masalah fisika SMA ditinjau dari sikap ilmiah siswa. Jurnal Ilmiah Profesi Pendidikan, 5(1): $35-42$.

Astuti, N.T, Sugiyarto, K.H., \& Ikhsan, J. (2020). Effect of 3D Visualization on Students' Critical Thinking Skills and Scientific Attitude in Chemistry. International Journal of Instruction. 13(1), 152-164

Ates, Ozlem., \& Eryilmaz, Ali. Effectiveness of hands-on and minds-on activities on students' achievement and attitudes towards physics. Asia-Pacific Forum on Science Learning and Teaching. 12(1), 1-22

Carin, A., \& Sund, B. (1989). Teaching Science Through Discovery. Columbus, Ohio: Merril Publishing Co.

Creswell, J. W. (2012). Educational research: Planning, conducting, and evaluating quantitative and qualitative research (4th ed.). Boston, MA: Pearson

Devi, M.G \& Aznam, N. (2018). The effect of science-technology-society (STS) model on scientific literacy and scientific attitude of students on the subject of buffer. International Conference of Chemistry (ICCHEM). Conf. Series 1156.012027.

Dewi, IGACK, Sadia, I.W., Sudria, I.B.N. (2020). Development of Physics Learning Device Based Science Technology Society (STS) Learning Model to Improve Scientific Attitude and Students' Understanding Concept of X Grade High School. Journal of Physics: Conference Series 1503012024.

Diani, R., Khotimah, K., Khasanah. U \& Ridho, M. S. (2019). Scaffolding In Physics Learning Based On Problem 
Based Instruction (PBL): The Effect On Concept Understanding And Self Efficacy. Indonesian Journal of Science And Mathematics Education 02(3): 310-319

Estapa, A. T., \& Tank, K. M. (2017). Supporting integrated STEM in the elementary classroom: a professional development approach centered on an engineering design challenge. International Journal of STEM Education, 4(6), 1-16.

Fadiran O.A., van Biljon J., \& Schoeman, M.A., (2020). Knowledge Transfer in Science Education: The Case for Usability-Based Knowledge Visualization Guidelines. In: Hattingh M., Matthee M., Smuts H., Pappas I., Dwivedi Y., Mäntymäki M. (eds) Responsible Design, Implementation and Use of Information and Communication Technology. I3E 2020. Lecture Notes in Computer Science, vol 12067. Springer, Cham.

Firdaus, \& Darmadi. (2017). Shaping scientific attitude of biology education students through research-based teaching. The 4th International Conference on Research, Implementation, and Education of Mathematics and Science. DOI: 10.1063/1.4995214.

Fitriani, A., Zubaidah, S., Susilo, H., \& Muhdhar, MHIA. (2020). PBLPOE: A Learning Model to Enhance Students' Critical Thinking Skills and Scientific Attitudes. International Journal of Instruction. 13(2).. 89106.

Fraenkel, J. R. (2012). How to design and evaluate research in education. Boston: McGraw Hill., Skills and Scientific Attitudes

Hadiati, S., Kuswanto, H., Rosana, D., \& Pramuda, A. (2019). The Effect of Laboratory Work Style and Reasoning with Arduino to Improve Scientific Attitude. International Journal of Instruction .12, (2): 321-336

Hidayati, L., Savalas, L.R.T., \& Purwoko, A.A. (2020). The Effect of Scientific Attitude and Motivation to Learn the Creative Thinking Skills of SMA/MA Student in Montong Gading Lombok Timur. International Conference on Science and Technology (ICST). 1.240-248

Ilmi, M.A., Sukarmin, \& Sunarno, W. (2020). Development of TPACK based-physics learning media to improve HOTS and scientific attitude. Journal of Physics: Conference Series. 1440012049.

Irnin, A. D. A. (2016). Peningkatan Kemampuan Berpkir Kritis Mahasiswa Melalui Model Pembelajaran Problem Based Intruction (PBI) pada Mata Pelajaran Kuliah Filsafat Sains. Jurnal Pendidikan Fisika Universitas Muhammadiyah Metro. 4(2). 68-75

John, O. K., \& Ademola, O. R. (2014). Scientific attitude, attitude to science and science achievement of senior secondary school students in Katsina State, Nigeria. Journal of Educational and Social Research, 4(1), 445452.

Kareem, A.O., Adeleke, MA, \& Salami, MO. (2020). Process skills application and scientific attitudes of Biology students in colleges of education in southwestern Nigeria. African Journal of Teacher Education. A Journal of Spread Corporation. AJOTE. 9: 80-103

Karim \& Normaya. (2015). Kemampuan Berpikir Kritis Siswa Dalam Pembelajaran Matematika Dengan Menggunakan Model Jucama Di Sekolah Menengah Pertama Banjarmasin: Jurnal Pendidikan Matematika. 3: 1:92-164

Kurniawan, D.A., Astalini., Darmaji., \& Melsayanti, R. (2019). Students' attitude towards natural sciences. International Journal of Evaluation and Research in Education (IJERE). 8(3), 455 460.

Lia, A. \& Derlina. (2016). Efek Penggunaan Pembelajaran Inquiry Trainning Perbantuan Media Visual dan Kreativitas Terhadap Keterampilan Proses Sains siswa. Cakrawala Pendidikan. 35 (2), 153-63.

Mayangsari, F., Maimunah., \& Fitryawany. (2019). Penerapan Model Pembelajaran Inkuiri untuk Meningkatkan Sikap Ilmiah Siswa pada Materi Gerak Lurus Di MAN Darussalam Aceh Besar. Jurnal Phi: Jurnal Pendidikan Fisika dan Fisika Terapan. 1: 9-16

Minan, C. M. (2016). Penerapan Pendekatan Inkuiri Terbimbing dengan Metode Pictorial Riddle untuk Meningkatkan Pemahaman Konsep Fisika Siswa. Jurnal Pendidikan Fisika, 4.(2), 111-23.

Muliani, A., Suastra, W. I., \& Suswandi, I. Implementasi Model Pembelajaran Inkuiri Terbimbing untuk Meningkatkan Sikap Ilmiah dan Prestasi Belajar Fisika Kelas XI SMA Tahun Pelajaran 2018/2019. JPPF Undiksha. 9(1), 55-62

Nugraha, I., Putri, N.K., \& Sholihin, H. (2020). An Analysis of the Relationship between Students' Scientific Attitude and Students' Learning Style in Junior High School. Journal of Science Learning. 3(3).185-195.

Parwati, G.A.P.U., Rapi, N.K., \& Rachmawati, D.O. (2020). Penerapan Model Pembelajaran Inkuiri Terbimbing untuk meningkatkan Kemampuan Berpikir Kritis dan Sikap Ilmiah Siswa SMA. Jurnal Pendidikan Fisika Undiksha, 10(1): 49-62.

Saepudin, A. (2020). Project Based Learning Implementation to Student's Scientific attitude and creativity improvement. Jurnal Mangifera Edu, 5(1), 64-77.

Şentürk, E., \& Özdemir, Ö. F. (2014). The effect of science centers on students' attitudes towards science. International Journal of Science Education, Part B: Communication and Public Engagement, 4(1), 1-24.

Stacey O. et al. (2018). The Globalization of Science Education and Science Curricula: Discussion and Conclusions. In: The Globalization of Science Curricula. IEA Research for Education (A Series of In-depth 
Analyses Based on Data of the International Association for the Evaluation of Educational Achievement (IEA), 3. Springer, Cham.

Sudarmini, Y., Kosim, S., \& Aos. (2015). Pembelajaran Fisika Berbasis Inkuiri Terbimbing dengan Menggunakan LKS untuk Meningkatkan Keterampilan Berpikir Kritis Ditinjau dari Sikap Ilmiah Siswa Madrasah Aliyah Qamarul Huda Bagu Lombok Tengah. Jurnal Penelitian Pendidikan IPA, 1(1), 35-48.

Sukarni, W., Jannah, N., Qoriyana, D., \& Zain, M.S., Scientific Attitude Identification and Interest of Pursuing Career in The Physics. Tarbiyah: Jurnal Ilmiah Kependidikan. 9(1), 66-77.

Suryani, W., Aji, S. D., \& Sundaygara, C. (2019). Pengaruh model pembelajaran inkuiri terbimbing dan sikap ilmiah terhadap prestasi belajar fisika. Prosiding Seminar Nasional FST Universitas Kanjuruhan, 2, 341-346.

Wijaya, S.A., Medriati, R., \& Swistoro, E. (2018). Pengaruh Model Pembelajaran Berbasis Masalah terhadap Kemampuan Pemecahan Masalah Fisika dan Sikap Ilmiah siswa di SMAN 2 Bengkulu. Jurnal Kumparan Fisika. 3(1): 28-35

Van Uum, M.S.J., Peeters, M. \& Verhoeff, RP (2019). Professionalising Primary School Teachers in Guiding Inquiry-Based Learning. Res Sci Educ. DOI: https://doi.org/10.1007/s11165-019-9818-z. 